\title{
Identification of Groundwater Quality of Alluvium Zone Using Geoelectric Method of Schlumberger Configuration in Merauke City Area
}

\author{
Virman \\ \{virman_uncen@yahoo.com\} \\ Physics Education Program, Departement of Sains, Faculty of education, Cenderawasih of University. \\ J1. Raya Sentani-Abepura Jayapura, Indonesia

\begin{abstract}
Clean water is needed for our daily activities such as drinking, cooking, bathing, washing, latrines, etc.Therefore, the provision of clean water is essential because it directly affects the regularity of human activity.Merauke city which is located at an altitude of -4 above sea level, composed by the youngest rocks aged Miocene. This condition possesses a risk that tides may intrude seawater to the land or intrusion, and this event would cause the impact of a clean water crisis.Based on the importance of clean water, the research was conducted in Merauke District of Merauke Regency.The research used geoelectric resistivity method of Schlumberger configuration type which is aimed to identify groundwater quality in alluvium zone with the youngest rock of Miocene age.The results of data processing show that there are two types of groundwaterin the study area, namely free groundwater and distressed groundwater. The resistivity of distressed groundwater type is $0.0772 \mathrm{ohm} \mathrm{m}$ which can be found at a depth of 51.1 meters, water with this type of resistance is indicated as polluted or brackish water.Meanwhile, free groundwater is located at a depth of 11.2 meters with a resistance type of $2.78 \mathrm{ohm} \mathrm{m}$ is also categorized as brackish water.
\end{abstract}

Keywords: brackish water, resistivity, Miocene, aquifer

\section{Introduction}

Merauke, the capital city of Merauke Regency, Papua Province, Indonesia. Geographically located on the southern coast of Papua, flat topography with a height of between 3-4 meters above sea level. Annual rainfall reaches $1,558 \mathrm{~mm}$, air temperature between $23-32^{0} \mathrm{C}$ and tropical climate. The total population of Merauke Regency as of December 31, 2017, according to data collection from the Department of Population and Civil Registry amounted to 278,200 people. Population density coupled with industrial activities in the city of Merauke causes the need for clean water continues to grow.

People in Merauke City are experiencing difficulty of clean water, one of the causes is the clean water production of local water company (PDAM)Merauke city is not increased. Access to clean water in Merauke District is not maximal, causing the development of water seller services in Merauke City, (Erwin, 2011).

Based on the problem, these research activities aimed at identifying groundwater quality of alluvium zone aged Miocene. Groundwater according to Thomas at al. (2009) is one of the many solutions found especially in big cities when the availability of surface water is increasingly limited. Meanwhile, according to Anomohanran (2013), he said that groundwater existence is uncertain in both depth and spread laterally. Similarly, groundwater quality is 
highly dependent on many things such as seawater intrusion, leachate pollution from waste piles, agriculture (fertilizer use) and so on.

Although groundwater cannot be seen from the soil surface, there are many ways that can provide information about groundwater availability and groundwater conditions from either the surface or on the surface of AgungRiyadi (2004). The groundwater investigation is indirectly known as geophysical prediction. The most widely used geophysical prediction for groundwater dispersion is the geoelectric resistivity method.

The utilization of geoelectric method for groundwater quality identification has been done by several experts such as Hajito (2013), Purnama et al (2006), Todd (1980), and Olhoeft (1981). According to Harjito (2013) geoelectric is good to estimate the potential groundwater based on the measurement of data that is the depth of the water table and the thickness of the aquifer. Purnama et al. (2006) utilizes geoelectric methods to estimate groundwater potential, and assumes that geoelectric methods have advantages because geo-electric appliances are portable, easy to operate, fast to measure, low operational costs, rapid data acquisition, and more accurate to produce results. Meanwhile, Todd (1980) and Olhoeft (1981) utilize geoelectric to map an aquifer basin of an area which can be used for planning and managing water supply in an area such as determining the location of drilling wells for residential, plant, and irrigation purposes. The location of the measurement of both sounding points, as in Figure 1 , is attached.

\subsection{General Geology of Research Areas}

Based on the Geological Map of the study, geologically, Merauke City is included in the crust of the Australian Continent (Heryantoat al ., 1995). The youngest rocks in this area are surface deposits deposited on the Holocene, consisting of Young River Sediment, Old River Sediment, Young Swamp Sediment, and Coastal Sediment.

Young River Sediment litologically is looseclastic clay consisting of sand, mud and gravel.

Old River Sediment is clastic sediment consisting of mud, sand and gravel. Old River Sediment is the result of compact flood plain sediment. Both sediments of the river above are still ongoing to this day

Young Swamp Sediment comprises the composition of clay, silt, and fine sand, containing carbonate material. The sediment deposition is still active.

Old Swamp Deposition is clastic fine clay sediment consisting of mud and fine carbonaceous sand, and peat. Coastal Sediment is generally a loose, fine-grained clastic sediment, consisting of mud and coarse-fine sand.

The surface sediments are not aligned above the Buru Formation aged Central Miocene PlioPlistocene, the rocks consisting of clay, granules, limestone, conglomerates of various materials and lignite.

\subsection{Basic Theory of Geoelectric}

The basic principle of geophysical method is the existence of anomaly, namely the difference of the physical quantity of the object being searched through the soil covering it.

The physical quantity for the geoelectric resistivity method is the electrical properties. Geophysical methods which utilize electrical properties include resistivity type, self-potential and impact polarization (Telford et al., 1990). 
The physical quantity for the geoelectric resistivity method is the electrical properties. Geophysical methods which utilize electrical properties include resistivity type, self-potential and impact polarization (Telford et al., 1990).

Geophysical research to determine the conditions below the earth's surface involves measurements on the Earth's surface from the physical parameters possessed by rocks in the earth. From these measurements, it can be interpreted how the properties and conditions beneath the surface of the earth either vertically or laterally (Telford et al., 1990).

Geoelectric method is one of the geophysical methods which use isotropic homogeneous assumptions. When an electric current is streamed into the earth, the current will flow in all directions and form a half-balled equipotential field. The flow of electric current in the earth is shown in Figure 2.

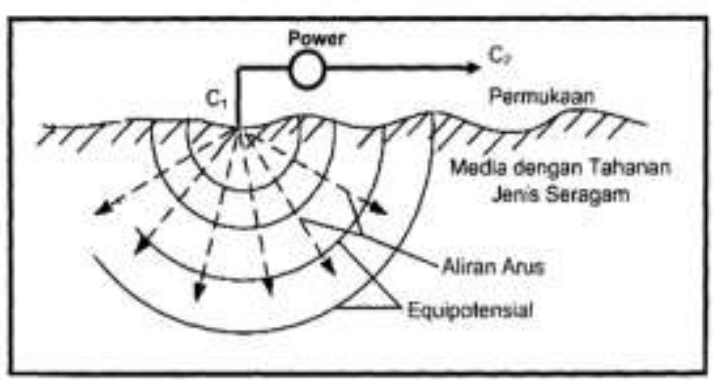

Fig. 1. Source of current in the soil surface of homogeneous media (Telford et al., 1990)

In general, earth resistivity is not homogeneous, meaning that the calculated resistivity is apparent resistivity. The apparent resistivity value can be calculated using the equation below:

$\rho a=K \frac{\Delta V}{I}$

Where $\rho_{\mathrm{a}}$ is apparent resistivity type, $\mathrm{K}$ is geometry factor, $\Delta \mathrm{V}$ is potency difference between both electrode potencies, and I is injected strong current.

Resistivity type in geoelectric method according to Purnamaet al. (2006) is determined better by porosity, water content, and water quality. In aquifer composed of loose material, the resistivity value will decrease (up to $2 \mathrm{ohm} \mathrm{m}$ ) due to the well conducive nature of electric current. According to Venkata et al. (2015), the resistivity type in sedimentary rocks such as in clay or sand saturated with salt water is less than $1 \mathrm{ohm} \mathrm{m}$. In basalt rocks as well as dry sand and pebbles, the resistivity value can reach thousands of ohms $\mathrm{m}$, while sands and gravel saturated, its freshwater resistivity is between $15-600 \mathrm{ohm} \mathrm{m}$. According to Irepia at al. (2015), the resistivity value of several types of earth material can be seen, as in Table 1.

Table 1. Resistivity value of earth material (Irepiaet al., 2015).

\begin{tabular}{ll}
\hline Material & Resistivity Range $(\Omega \mathrm{m})$ \\
\hline Andesite & $10^{3}$ (basah) $-1.7 \times 10^{5}$ (kering) \\
\hline Sandstone & $1-6.4 \times 10^{8}$ \\
\hline Limestone & $50-10^{7}$ \\
\hline Clay & $1-100$ \\
\hline
\end{tabular}




\begin{tabular}{ll}
\hline Consolidated Shales & $20-2 \times 10^{3}$ \\
\hline Granite & $3 \times 10^{2}-10^{6}$ \\
\hline Diorit & $10^{4}-10^{5}$ \\
\hline Gabbro & $10-1.3 \times 10^{7}$ \\
\hline Basalt & $10^{3}-6 \times 10^{4}$ (basah) \\
\hline Alluminium & $10-800$ \\
\hline Gravel & $100-600$ \\
\hline Water in aquifer alluvium & $50-5 \times 10^{2}$ \\
\hline Sand and gavel are submerged in seawater & $0.5-5$ \\
\hline Seawater & 0.2 \\
\hline Sand & $1-1000$ \\
\hline
\end{tabular}

Based on equation 1, the value of $\mathrm{K}$ (geometric factor) for thegeoelectric resistivity method consists of various rules used to place four electrodes. The rules of placement of these four electrodes in geophysical terms are commonly referred to as electrode configurations (Hendrajaya, L., 1990). Although there are many different types of electrode configurations, the most commonly used are Wenner, Schlumberger, Dipole-dipole and Rectangle electrode configurations. Rectangle electrode configuration is rarely used because of its slightly difficult settings.

In this research, the Schlumberger configuration is used (Figure 3). For rules of Schlumberger configuration, space electrode of far current is wider thanpotential electrode space.

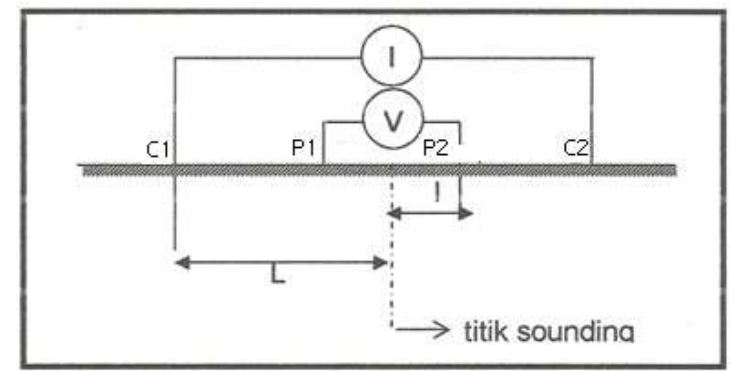

Fig. 2. Schlumberger Configuration (Telford et al ., 1990)

Generally, Schlumberger method is conducted with distance electrode current of C1 - C2 made 10 times or farther than potential electrodes of P1-P2. Every configuration has a different penetration depth, so in measurement, penetration depth is one of the factors which are considered in the selection of electrode configuration. The other factors are structure type, tool sensitivity, and available noise level. 


\section{Method}

The study area is located in Merauke District and is geographically located at the coordinates of $140^{\circ} 25^{\prime} 12.5^{\prime \prime}$ EL and $08^{\circ} 30^{\prime} 45.4^{\prime \prime}$ SL (attached).

The used measuring equipment is Geoelectric device of Noniura NRD 328 HF equipped with several supporting equipment such as car batteries, electrodes, cable, umbrella, hammer, meter tool, Global Positioning System (GPS) and Geothermal Map Sheet of Merauke scale 1: 250.000. Prior to measurement, a preliminary survey was conducted to seek a position which was considered representative (considering the nature of the research area). Based on the results of this preliminary survey, in the study area, there were two paths measured, namely the 001 / Kipan A with north-south trajectory and the 001 / Kompi E with west-east trajectory.

In the field, a soundingsystem is used to obtain a vertical lithologic picture at the point of prediction. Lateral spread of a lithologic unit can be obtained by performing a one-point sounding prediction with other sounding points. In the Schlumberger configuration used in this study, the distance of the P1-P2 potential electrode is started on 1/3 of the distance of the $\mathrm{C} 1-\mathrm{C} 2$ current electrode. Furthermore, the prediction measurement is made only by moving the current electrode to a distance where the potential difference measurement of $\mathrm{P} 1-\mathrm{P} 2$ results has shown a small value, then P1-P2 is widened gradually as determined, so that the curve obtained meets the existing standard curve.

This geoelectric measurement data of the Schlumberger configuration (Figure 1) is collected in the form of current $(\mathrm{mA})$ and potential difference (volts). This data (current and potential difference) are obtained by injecting an electric current through two current electrodes, whereas in order to obtain deeper penetration, electrode transfer of both current and potential electrodes isperformed.

The data resulted from measuring potential difference (volt) and current (mA) in two different locations, then, were recorded according to their positions using GPS. This process is intended to ease the search whenever the data are needed, while the results of the measurement of the next type of resistivity is processed using equation 1 to obtain apparent resistivity. As for the true resistivity, IPI2win software was used.

Data analysis of the resistivity type was done by referring to the concept developed by Telford et al. (1999). According to Telford et al. (1999), the value of a rock resistivity type has a considerable big value range (Table 1), this is caused by several factors, namely its forming material, density, porosity, pore shape as well as size, and saturation level. The relatively more porous rock and its electrical conductivity discharge is more influenced by the amount of fluid it contains than the forming material.

Based on the resistivity value for each layer of rock obtained, the next step is the lithologic interpretation and possible water content prediction by considering geological and hydrogeological data. Comparative lithologic conditions are carried out for each guessing point, so that the direction of the groundwater flow can be predicted as well as the area where the groundwater accumulates. Thus, the possible points for drilling exploration can be determined based on the results of the analysis.

\section{Results And Discussions}

This study was conducted by analyzing the measurement data of electric current (I) and potential difference $(\mathrm{V})$ of each measurement path calculated into the pseudo-resistance value. The data of field measurement results (apparentresistivity type), then, were processed by using IPI2win software. This was done to produce a geoelectric cross section of subsurface 
resistivity type. Based on this geoelectric section, it can be known the depth and the structure of soil layers that potentially contain groundwater based on different types of resistivity values. The geoelectric section of the subsurface resistivity type is shown in Figs. 4 and 5 . Furthermore, for lithologic interpretation, the correlation between the rock resistance and rock resistivity type value was conducted and can be seen in the reference (Table 1).

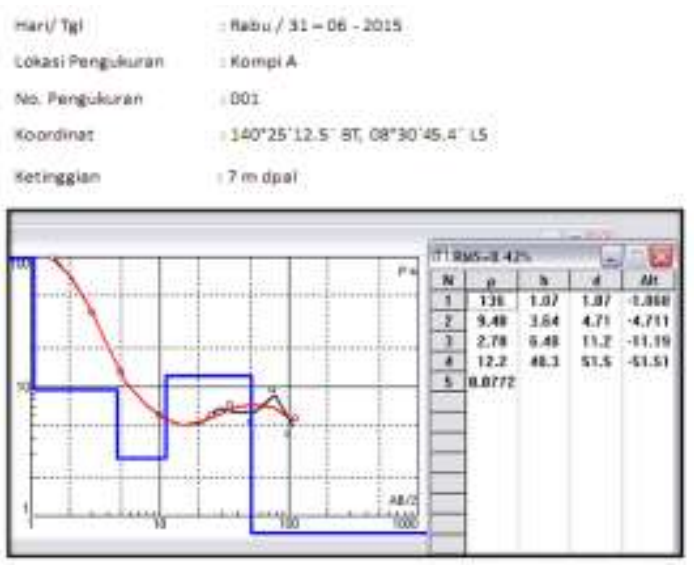

Fig. 3. Geoelectric section of the subsurface resistivity on the 001line (Kompi A).

Based on Figures 5 and 6, the result of data processing using IPI2win software shows the resistivity type of $0.0772-136 \mathrm{ohm} \mathrm{m}$. By matching these types of resistors with Table 1 and other supporting data such as geological data (Figure 2), we could interpret each type of rock as follows:

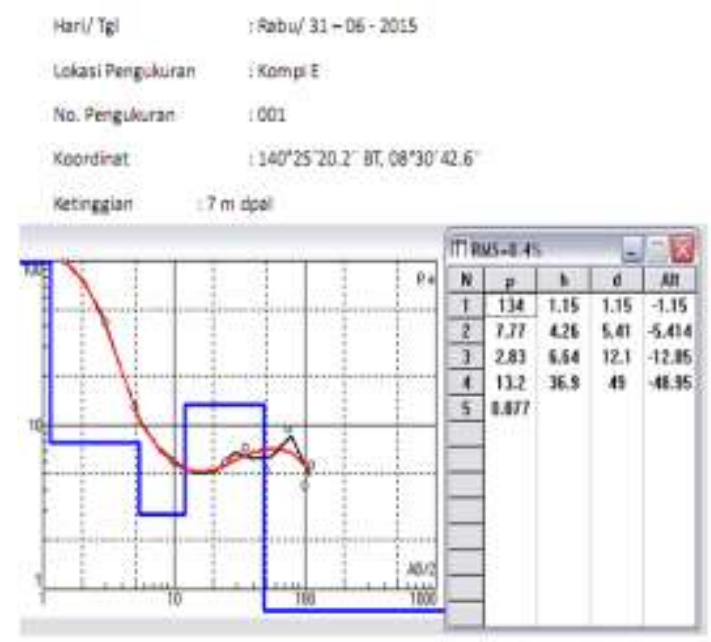

Fig. 4. Geoelectric section of the subsurface resistivity on the 001 line (Kompi E). 
The first layer has the resistivity type value of $136 \mathrm{ohm} \mathrm{m}, 1.07 \mathrm{~m}$ thickness and $1.068 \mathrm{~m}$ depth, and is the most resistive layer of the rock type in the form of clay sand. This type of high resistivity value was caused by the point of measurement which was right on the road (having already been hoarding) so that the soil structure was not only more compact but also its water content was also relatively less. The clay-sand layer, according to Telford, (1990) includes an impermeable layer, therefore it is possible that even in this layer there is groundwater but still in small quantities.

The second layer has the resistivity type value between $7.77-9.48 \mathrm{ohm} \mathrm{m}$, and is at a depth of $4.7-5.41 \mathrm{~m}$. This second layer was thought to be a sand layer mixed with clay. While sand is a rock material that can pass water, but with the insertion of clay, this layer could store water and distribute it in limited quantities.

The third layer has the resistivity type value of $2.78-2.83 \mathrm{ohm} \mathrm{m}$. This layer is based on the resistivity value, also classified as conductive, it was estimated that the structure is sandy clay. Clay has properties that can absorb or release $\mathrm{H}+$ ions, this property will determine the acidity of soil or groundwater (Notodarmojo, 2005). This is also in line with research conducted by Purnamaet al. (2006) which states that the presence of clay layer will reduce the resistivity type value reaching about $2 \mathrm{ohm} \mathrm{m}$. This is due to the well conductive nature of clay.

The fourth layer has the resistivity type value of $12.2-13.2 \mathrm{ohm} \mathrm{m}$. Based on the resistivity type value and assisted by supporting data in the form of geological data and some wells of the inhabitants, then this layer of structure in the form of sand and gravel was predicted as an aquifer. According to Venkata et al. (2015), gravel and sand allow the presence of groundwater because gravel and sand have large porosity and permeability, and groundwater is between the pores of the sand and gravel. Thus, this layer is potentially groundwater with aquifer thickness of 30 to 40 meters. Based on the environmental geology of the research area, the solution may be the ancient subsurface canal.

The fifth layer has the resistivity type value between $0.0772-0.077 \mathrm{ohm} \mathrm{m}$, and it is at a depth of $>51.51 \mathrm{~m}$. In this layer the structure is clay of sand. This layer when compared with the layer above, the structure is more subtle. According to Jopony (2005), finer grain structure has more metal content. The metal content in this layer is considered as one of the factors causing the value of the resistivity type to be smaller. Another factor related to the small value of the resistivity type is temperature and water type. The deeper the depth, the higher the temperature. This can be seen in the wells in Jakarta, groundwater is being sucked at depths above 100 meters of hotter in temperature than shallow groundwater.

\section{Conclusion}

The resistivity value toward the observation point shows a consistent pattern. These results indicate that the geoelectric method can be used to predict groundwater quality of the alluvium zone aged Miocene.

The compilation results of the data in the study area indicate that it was identified in the study area the existence of free groundwater and distressed groundwater. Both types of groundwater indicate that the research area in quantity is not havingshortage; in contrast, it has an abundance of groundwater. However, in the aspect of water quality, the water cannot be consumed as drinking water because the water smells of sulfur. This was indicated by the low resistivity of elastic rock types reaching $0.0772 \mathrm{ohm} \mathrm{m}$. 


\section{References}

[1] Anomohanran, O. 2013. Investigation of Groundwater Potential in Some Selected Towns in Delta North District of Nigeria. International Journal of Applied Science and Technology. Vol. 3. 61-66.

[2] Erwin, E.P. 8 September 2011. Our Well Water tastes salty. Kompas, hal. 3.

[3] Harjito., 2013. Method of vertical electric sounding (VES) to predict potential water sourceday Jurnal Sains dan Teknologi Lingkungan. Vol. 5 No. 2: 127 - 140.

[4] Hendrajaya, L., 1990.Geophysical methods . Semarang: Universitas Negeri Semarang.

[5] Heryanto, R., dan Pangabean, H., 1995. Map of geology bersisitem Indonesia sheet Merauke - 3407, Irian Jaya. Skala $1: 250.000$

[6] Irepia, R. D., Akman, dan Nofi, Y. S., 2015.Identify the slip field using geolistrik method of resistivity of configuration type of Schlumberger in Bukit Lantiak District of Padang Selatan. Jurnal Pillar of Physics. Vol. 5: $01-08$.

[7] Jopony, M., Usu, G., dan Muhamed, M., 2005. Particle size distribution of copper mine tailling from Lohan Ranau Sabah and its relationship with heavy metal conten. Journal Pertanika. V. 10, 37-40.

[8] Notodarmojo, S., 2005.Soil and groundwater pollution. Penerbit ITB.

[9] Olhoeft, G. R., 1981. Physical properties of rock and minerals: Electrical properties of rocks, edited by Y. S. Youloukian, W. R. Judd \&

[10] R. F. Roy, McDrow Hill Book Company, New York.

[11] Pemda Kabupaten Merauke., 2006.Investment Profile of Merauke Regency.

[12] Purnama, Ig. S., dan Sulaswono, B., 2006.Utilization of geoelectric technique to detect saltwater ground distribution in free aquifers in Surabaya City. Majalah Geografi Indonesia. Vol. 20 No. 1: 52 - 66.

[13] Subarnas A. 2014. Inventory of peat sediment in Merauke Regency, Papua Province.

[14] Telford, W. M., Geldart, L. P., dan Sherif, R. E., 1990. Applied Geophysics, Cambridge University Press, New York.

[15] Thomas, T. P., dan Kristi, I. K., 2009.Groundwater problems in urban areas. Jurnal Teknik. Vol. 30 No. $1.48-56$.

[16] Todd, D. K., 1980. Groundwater hidrogeology. John Wiley \& Sons, New York.

[17] Venkata Rao, P. Kalpana and R. Srinipasa Rao. 2015. Groundwater Investigation using Geophysical Methods a Cese Study of Pydibhima Varam Industrial Area. International Journal of Reasearch in Enggineering and Technology. vol.03. p. 13-17.

\section{Attachment: Location of geoelectric measurement points}




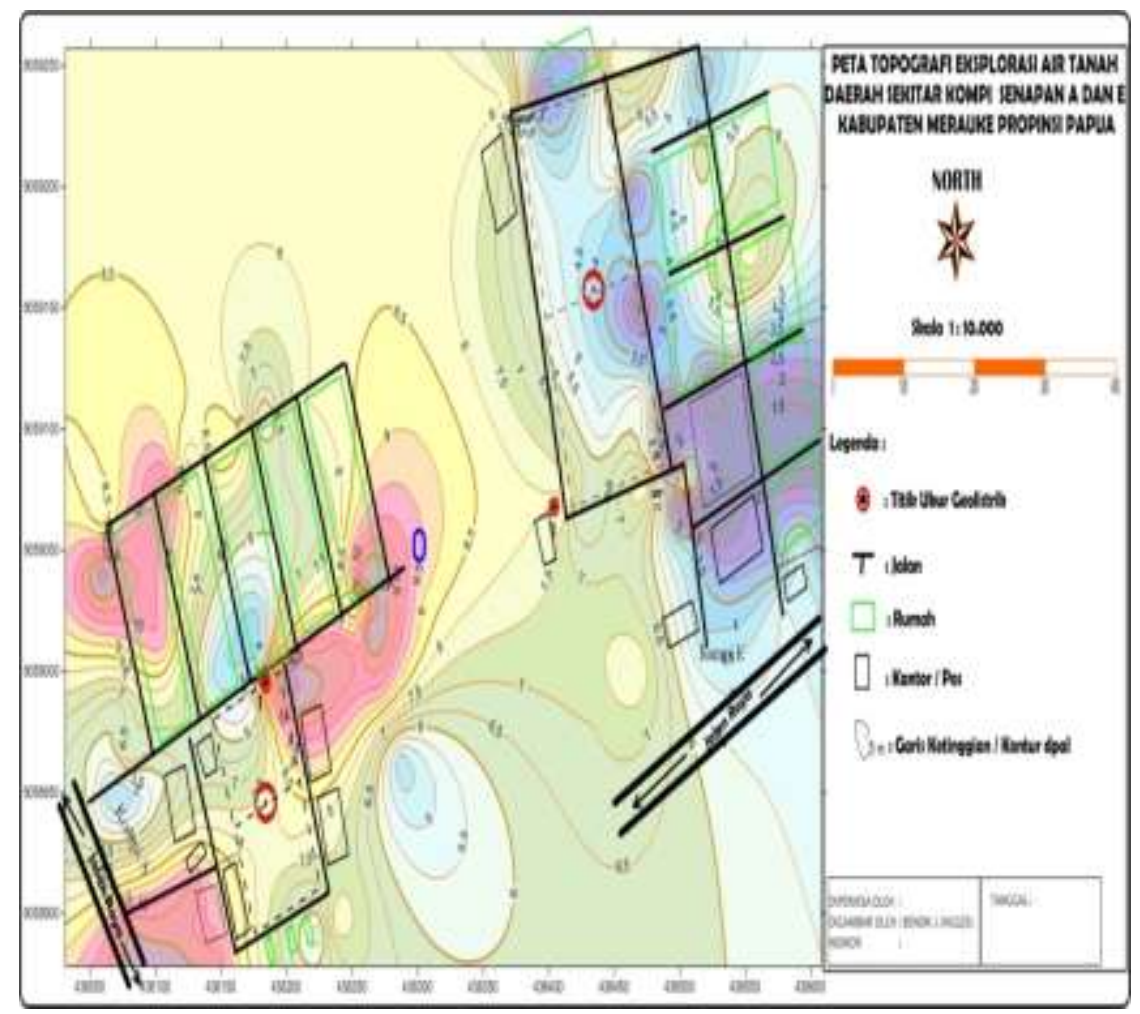

Fig. 5. Location of geoelectric measurement points in Merauke District 